\title{
Archipel
}

ARCHIPEL Études interdisciplinaires sur le monde insulindien

$100 \mid 2020$

Varia

\section{Inscriptions of Sumatra, IV: An Epitaph from Pananggahan (Barus, North Sumatra) and a Poem from Lubuk Layang (Pasaman, West Sumatra)}

Inscriptions de Sumatra, IV : une épitaphe de Pananggahan (Barus, SumatraNord) et un poème de Lubuk Layang (Pasaman, Sumatra-Ouest)

\section{Arlo Griffiths}

\section{OpenEdition}

Journals

Édition électronique

URL : http://journals.openedition.org/archipel/2067

DOI : 10.4000/archipel.2067

ISSN : 2104-3655

Éditeur

Association Archipel

Édition imprimée

Date de publication : 15 December 2020

Pagination : $55-68$

ISBN : 978-2-910513-84-9

ISSN : 0044-8613

\section{Référence électronique}

Arlo Griffiths, «Inscriptions of Sumatra, IV: An Epitaph from Pananggahan (Barus, North Sumatra) and a Poem from Lubuk Layang (Pasaman, West Sumatra) », Archipel [En ligne], 100 | 2020, mis en ligne le 28 novembre 2020, consulté le 04 décembre 2020. URL : http://journals.openedition.org/archipel/ 2067 ; DOI : https://doi.org/10.4000/archipel.2067 
ARLO GRIFFITHS $^{1}$

\section{Inscriptions of Sumatra, IV:An Epitaph from Pananggahan (Barus, North Sumatra) and a Poem from Lubuk Layang (Pasaman, West Sumatra) ${ }^{2}$}

The preceding report by Daniel Perret, Heddy Surachman \& Repelita Wahyu Oetomo on recent archaeological surveys in the northern half of Sumatra mentions inscriptions in Indic script found respectively near the Makam Ambar in Barus, North Sumatra, and at the village Kubu Sutan in nagari Lubuk Layang, kec. Rao Selatan, kab. Pasaman, West Sumatra. The purpose of this note is to publish my readings of these two inscriptions, both of which are written in Old Malay. ${ }^{3}$ The first, clearly an epitaph and almost certainly engraved to commemorate the death of a Muslim, according to the authors of the report, bears a date equivalent to 29 June $1350 \mathrm{CE}$, which makes it the earliest Islamic inscription in Indic script from Sumatra.

1. École française d'Extrême-Orient, Paris; UMR 5189, Histoire et Sources des Mondes Antiques, Lyon. The research for this article has been undertaken as part of the project DHARMA 'The Domestication of "Hindu" Asceticism and the Religious Making of South and Southeast Asia', funded by the European Research Council (ERC) under the European Union's Horizon 2020 research and innovation programme (grant agreement no 809994). See https://dharma.hypotheses.org.

2. For previous installments of my 'Inscriptions of Sumatra', see Griffiths 2011, 2012 and 2014 in the bibliography. I thank Andrea Acri, Dániel Balogh, Henri ChambertLoir, and especially Daniel Perret for their comments that helped me interpret the two inscriptions presented here.

3. Old Malay is here understood to be "the variant of the Malay language found in documents written in an Indic (i.e., Brāhmī-derived) system of writing" (Griffiths 2018: 275). For representing the Old Malay texts, I use the transliteration system proposed in Balogh \& Griffiths 2020. 


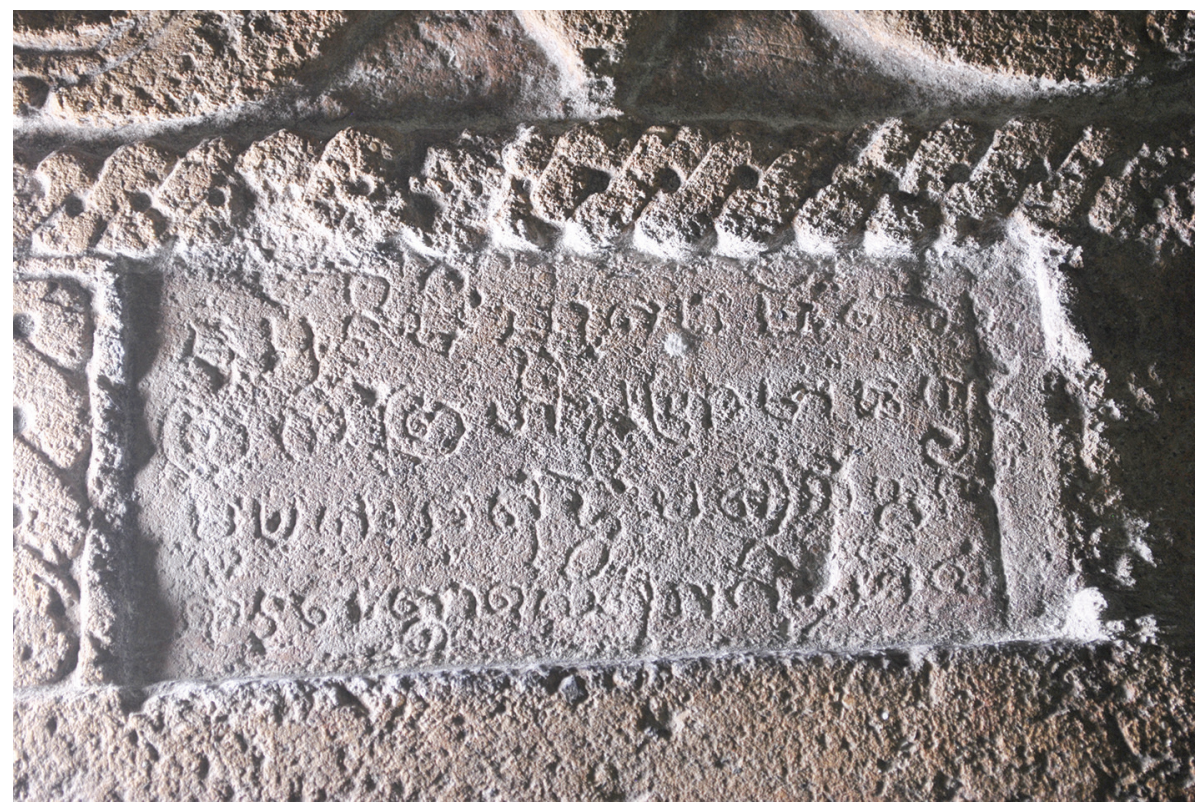

Fig. 1 - Photograph of the Pananggahan Old Malay inscription. Repelita Wahyu Oetomo, Sept. 2019.

The raison d'etre of the second inscription, datable to the same period, is less clear; this second inscription, almost certainly from a religious context where Islam had not yet penetrated, casts interesting light on the history of application of Indic verse forms to Nusantaran languages.

\section{The Pananggahan Tombstone}

The text is deciphered here from photos furnished by Daniel Perret, one of which is shown as fig. 1. I refer to the preceding report for photos showing the shape and decoration of the stone.

Text

(1) (vars)uri dim sākavarșa 1-

(2) 272 hi[lami] Ā(șā) dhha kr-

(3) șnapakșa caturdvimsat $\cdot(\mathrm{m})$ angala-

(4) vāra tatkāletu bhagi(n)da hilaṃ

\section{Commentary}

1. (vars)uri: This word is still obscure to me, and the reading therefore uncertain, although all constituents of vars seem detectable on the photographs and no clear alternatives present themselves for transliterating the engraved 
characters. Unless the text we have is the continuation of a preceding part engraved on another support, we expect here an auspicious word of the type $O \dot{m}$ or svasti that is normally found before a dating formula in the Indic inscriptions of Indonesia, including those of Northern Sumatra (see examples in Griffiths 2014: 217, 220, 225, 234). I have considered but rejected the possibilities (a) that we are dealing with a form of the ancient name of Barus ${ }^{4}$ or (b) that we have here a form of the word suri in the meaning "queen," any of the other meanings that this Malay word can have.

1. dim: understand din, i.e. /di-n/. For another epigraphic instance of the preposition $d i$ with the definite article $\dot{n}$, in the inscription Tandihat III from Padang Lawas, see Griffiths 2014: 225.

2. hi[laim]: I have no satisfactory hypothesis for reading the second syllable and interpreting this word. The reading tentatively chosen here is based on the assumption that we are dealing with scribal sloppiness, due to anticipating of the crucial verb form of this text that comes in its expected place at the end of the text. I have also considered the possibility that the word beginning with $h i$ here is some bisyllabic Arabic term suitable to the context, perhaps an allusion to the Hijra era, although this would not be more natural in the context than the word hilam is.

3. caturdvimsat : since it is incomprehensible if it means "four two six," this sequence probably has to be understood as corrupt form of the Sanskrit numeral caturvimśati "twenty-four." In the spelling caturvvimśati, this last word would look very close to caturdvimșat in the original script. See below p. 58.

4. tatkāletu: understand tatkāla itu, joined in vowel sandhi. On vowel sandhi in Old Malay texts, see my review in BKI 166 (2010): 137 (mentioning parāhüram = parahu orang in the Tanjung Tanah manuscript); there are also instances among the Old Malay inscriptions of West Sumatra (e.g., Bukit Gombak I, lines 13 and 15, sāsanenan = śäsana inan and dharmmenan = dharmma inan; Padang Roco, punyeni = punya ini). For discussion of the Old Malay expressions tatkāla itu = sana tatkāla, see Griffiths 2014: 225 and 227 and 2018: 279.

4. Because a toponym would hardly fit the context and one would expect to find in Indic script a spelling close to that given in a contemporary Indic text from Indonesia, the Deśavarnana, where one reads barus in stanza 13.2 hi lvas lāvan samudra mvañ $i$ lamuri batan lāmpuñ mvan் $i$ barus, yekādinyañ vatək bhūmi malayu "Lwas and Samudra, as well as Lamuri, Batan, Lampung and Barus - Those are the main ones among the Malay lands" (tr. Robson 1995).

5. Because in an inscription in Indic script, one would expect a form of the word closer to the Sanskrit parameśvarī. 


\section{Translation}

barsuri (?) In Śaka year 1272, demise, (month?) of Āṣāạha, waning fortnight, the twenty-fourth (day of the month), a Tuesday: that was the time of his/her highness' demise.

\section{The date}

The date is expressed in the Indian pañāinga ("five-element") calendar system, in a manner quite comparable to what we see in the aforementioned inscription Tandihat III from Padang Lawas, which is 171 years older (Griffiths 2014: 224-226). Our dating formula involves the following variables:

$\begin{array}{ll}\text { Era } & \text { Śaka } \\ \text { Year } & 1272 \\ \text { Month } & \overline{\text { Āsāâha }} \\ \text { Fortnight } & \text { krșa, i.e. waning } \\ \text { Number } & \text { caturdvimsat } \\ \text { Weekday } & \text { Mañgala, i.e. Tuesday }\end{array}$

In my interpretation above, p. 57, caturdvimșat is a localized form, if not to say an error, for caturvimśati and meant to indicate the $24^{\text {th }}$ civil day of a full month starting at new moon, i.e. the $9^{\text {th }}$ tithi of the waning fortnight. ${ }^{6}$ If one fills in the above parameters, while using the value 9 for the tithi, in the online date conversion software Pancanga, ${ }^{7}$ the result is June 29, 1350 CE, which date fell on the Tuesday required by the text. The result is confirmed by the software HIC, which I have used to create the diagram shown here as fig. 2. None of the other interpretations of caturdvimsat that have occurred to me, namely the values 14 (caturdaśa in Sanskrit) or 12 (catur $4+d v i 2+s a t$ 6 ), yield a result as satisfactory as the one I propose here. Why this date is expressed using civil day rather than tithi remains an open question. ${ }^{8}$

6. "Occasionally the day of the full month, undivided into fortnights, is given, either in place of or in addition to the tithi of the fortnight" (Salomon 1998: 174 n. 39). See Pingree 1982 for further details. Unfortunately, all of the examples of counting days of the full month given by Salomon and Pingree date to the first half of the first millennium CE.

\section{7. https://www.cc.kyoto-su.ac.jp/ yanom/pancanga/}

8. The only allusion to this counting system that I have so far been able to find in the seminal publications of Louis-Charles Damais about Indonesian dates is Damais 1952: 21 (about the $8^{\text {th }}$-century Hampran inscription from Central Java): "le nombre « 21 » fait penser à un comput solaire, par ailleurs inconnu à Java (il semble avoir existé — au moins à une date beaucoup [plus (AG)] récente — à Sélèbès en pays bugi)"; see also Damais 1955: 248 (about the same inscription): "nous ne croyons pas que les nombres au-dessus de 15 aient — au moins à Java — été employés dans un comput luni-solaire". 
If my interpretation is correct and if it may be assumed, with Daniel Perret, Heddy Surachman \& Repelita Wahyu Oetomo in their report on the discovery of this tombstone, that we are dealing with a specifically Islamic epitaph, then we must note the total absence of explicit indicators of the knowledge of Arabic language/script and of Islam in the Old Malay text, which would contrast with the other early Islamic inscriptions in Old Malay known so far, the ones from Minye Tujuh (Aceh) and Pengkalan Kempas (Negeri Sembilan, Malaysia). ${ }^{9}$ And, still assuming that the Islamic affiliation of this tombstone is a valid hypothesis, we may draw the conclusion that this tombstone, just a few decades more recent than the oldest dated Islamic tombstones that have so far been found on Sumatra, ${ }^{10}$ is indeed the oldest Islamic tombstone known so far from the Barus area. The Arabic epitaph previously claiming that honor was found at the exact same cemetery in Barus and bears a date also falling in $1350 \mathrm{CE}{ }^{11}$ but some months after June in that year. It is very regrettable that the Arabic inscription is damaged while the preserved part does not contain the name of the deceased person, which is apparently unmentioned in the Old Malay epitaph. Nevertheless, the correspondence of the shapes of the two tombstones has led the archaeologists to propose that the two might have marked a single grave. If that was the case, then we must find an explanation for the fact that the conversion of the Hijra date contained in the Arabic epitaph and that of the Saka date contained in the Old Malay epitaph does not lead to the exact same date in the common era, a situation somewhat different from the disagreement between dates observed in the case of the Minye Tujuh epitaphs, ${ }^{12}$ or the disagreement of dates between the texts written in Jawi and in Indic scripts on the Pengkalan Kempas tombstone. ${ }^{13}$ I must leave open the questions (1) whether there is any issue with the reliability of the conversion mechanisms applied to the Saka or Hijra dates on the two Pananggahan tombstones, (2) whether there are problems with the decipherment of the

\section{See van der Molen 2008 and De Casparis 1980.}

10. See Guillot \& Kalus 2008: 177-179, for stones dated 1297 (Malik al-Sâlih) and $1326 \mathrm{CE}$.

11. See Perret, Heddy Surachman \& Repelita Wahyu Oetomo in this volume, fig. 3.

12. "One problem is that the Arabic inscription, although referring to the same event, displays a different date: not $781 \mathrm{AH}$ but $791 \mathrm{AH}$ (1389 AD). As other details of the date are the same, it is generally assumed that a mistake was made in the second digit of the year in one of the two inscriptions" (van der Molen 2008: 356).

13. "[...] one of the riddles surrounding the Pĕngkalan Kĕmpas inscriptions: the approximately four years' difference between the dates given in the Kawi and Jawi inscriptions. [...] I can see only two possible solutions of the discrepancy between the two dates. The explanation which first comes to one's mind is that of a mistake in either or both of the dates. [...] In the light of these considerations it has to be concluded that both dates are correct, implying that the Kawi and the Jawi inscriptions are not contemporary" (De Casparis 1980: 6-7). 


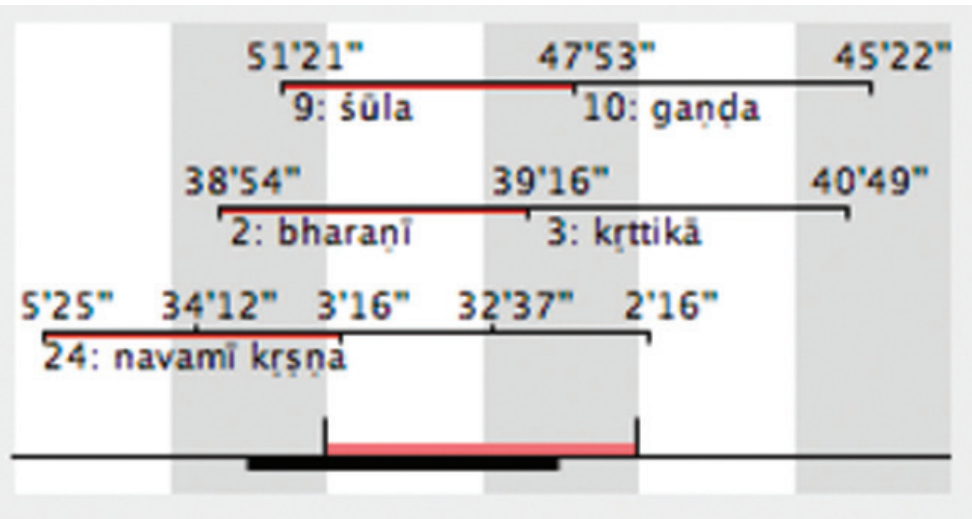

\section{|Śaka 1272 Āșạ̣̄ha \#24|}

\section{AD 1350 Jun 29 Tu}

Fig. 2 - Diagram showing the dating parameters of the Pananggahan tombstone inscribed in Old Malay.

Arabic text - in which two cases it may be possible to bridge the narrow gap between the two Barus epitaphs - or (3) whether the disagreement between the dates actually means that the two epitaphs do not belong to a single grave.

\section{The Lubuk Layang Stela}

This inscription, engraved in a form of script practically indistinguishable from the script that is typical of Ādityavarman's inscriptions, was discovered in the $1970 \mathrm{~s}^{14}$ and briefly mentioned by Satyawati Suleiman (1977: 2$)^{15}$ and Machi Suhadi (1990: 227, 1995-96: 21) before it was finally published by

14. The sources at my disposal mention various dates: April 1975 (Satyawati Suleiman 1977: 2), "sekitar tahun 1970" (Machi Suhadi 1990: 227), or 22 April 1976 (Hunter 2015: 324) — the latter date is the one indicated on the typescript that I consider to have been produced by Boechari, on which see n. 17 .

15. Satyawati Suleiman 1977: 2, with reproduction of an estampage of face B in plate 3. Her information is partly misleading: "The characters are Old Sumatran script, which look slightly different from the characters in Adityawarman's inscriptions, yet there are still enough similarities. The characters are very much unlike those used by the kings of Sriwijaya and also unlike Javanese characters. They have more similarities with the characters used in Cambodia. (according to Boechari)". 
Budi Istiawan (1994). ${ }^{16}$ Apparently unaware of this publication, Hunter (2015) reproduces an unpublished reading that he found among the papers of J.G. de Casparis kept at Leiden University. ${ }^{17}$ None of the existing publications is accompanied by reproductions allowing to verify the readings, and it does not appear to have been observed so far that the inscription is metrical in other words, that we are dealing with a poem -, while awareness of the metrical structure makes it possible to achieve a more reliable reading and interpretation. For these reasons, it may be useful to include my decipherment here, even though the text remains very challenging.

My reading is based on the estampages bearing the numbers n. 2005 and n. 2006 held at the EFEO in Paris, which were made during my 2011 campaign of documenting inscriptions in West Sumatra. In my edition, in lost parts whose metrical structure is known, I use - to indicate a lost short syllable, and - to indicate a lost long syllable. The breve sign - on top of a vowel means that it is short but needs to be read as long to suit the meter. ${ }^{18}$ The several instances of a closing symbol are here represented by the pilcrow sign (ף).

16. This article is based on an unpublished report by Budi Istiawan (1992).

17. Hunter (2015: 375 n. 60) attributes the typescript to De Casparis, but I suspect it is by Boechari, because various Indonesian publications refer to a reading by Boechari and it is likely that Boechari would have shared it also with De Casparis. The text printed by Hunter does not agree precisely with any of the readings I have myself copied in the De Casparis archives, but I suspect this may be due to typing errors on Hunter's part, and so I do not believe that he has seen a different document than the one I have, which exactly resembles the Boechari typescripts that I have collected in preparing the edition of Boechari's selected writings.

18. For general information on how Indic meters work, in a Nusantaran context, see Zoetmulder 1974: appendix III ("Kakawin metres"), pp. 451-472. 


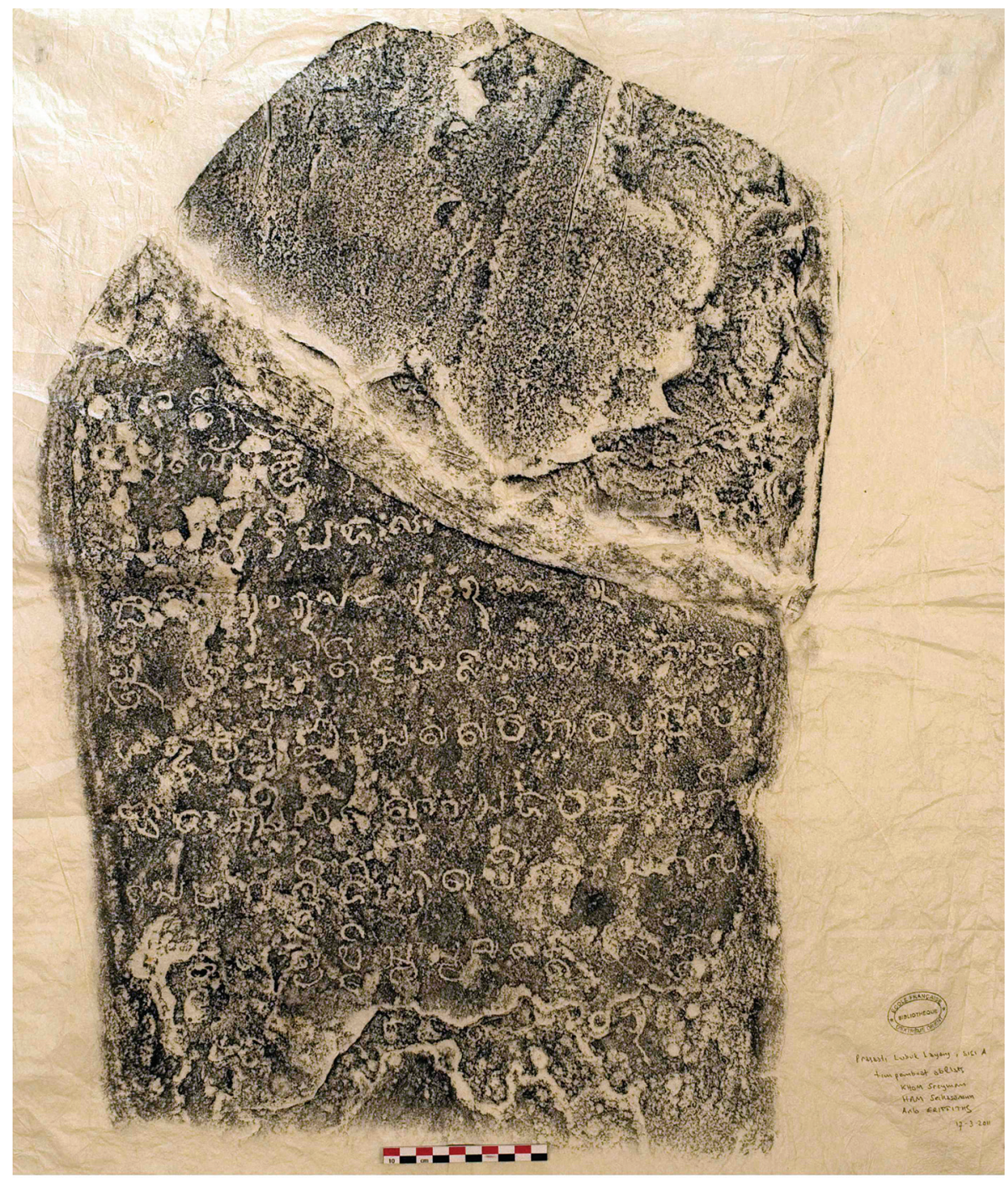

(两)

n. 2005 / N. Lubuk Layang A

Fig. 3 - Lubuk Layang stela, face A. Estampage EFEO n. 2005. Photo courtesy of the EFEO. 


\section{Edition}

A (East face, fig. 3)

(1) $\{2$ aks.. $\}$ I[ndra $]$...

(2) $\{1$ akș. $\}$ (pu)rṇ(n)endra(bh)u ...

(3) ra ma $\{1$ aks. $\}$ surimadaṇa ...

(4) dha(r)i[ṇi $]^{19} / / 0 / /$ // $0 / /$ // ...

(5) $\mathrm{Om}$

Amarabijaya yauvāsūk(șm)a jăy(6)endravarmman·, satatavibhava $\mathrm{p}(\overline{\mathrm{u}}) \mathrm{jā} p a(7)$ ñcadānăsila(ta)tvā, sadavaca(ṇa) bi(8)seșābhakti dī mātap̌̄tā, sakala(9)[ja](nas)utrptisvasthaśanto(ṣabandh) $[\mathrm{u}]^{20}$

(10) about 7 akșaras illegible $\mid 0 / /$

19. It seems likely that what precedes formed part of at least one stanza, but the damage is too severe to be able to reconstruct what the meter was.

20. The meter is Mālinī, containing four pādas, each of which has the pattern

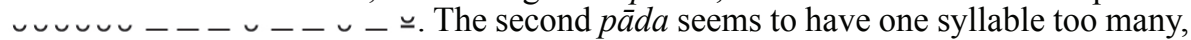
but I suspect that the unclear $t a$ in pañcadānasila(ta)tva was intended to be crossed out. In any case, the meter supports reading pañcadānăsilatva , and if this is understood as equivalent to pañcadānaśillatva, we can obtain a more or less plausible sense. 


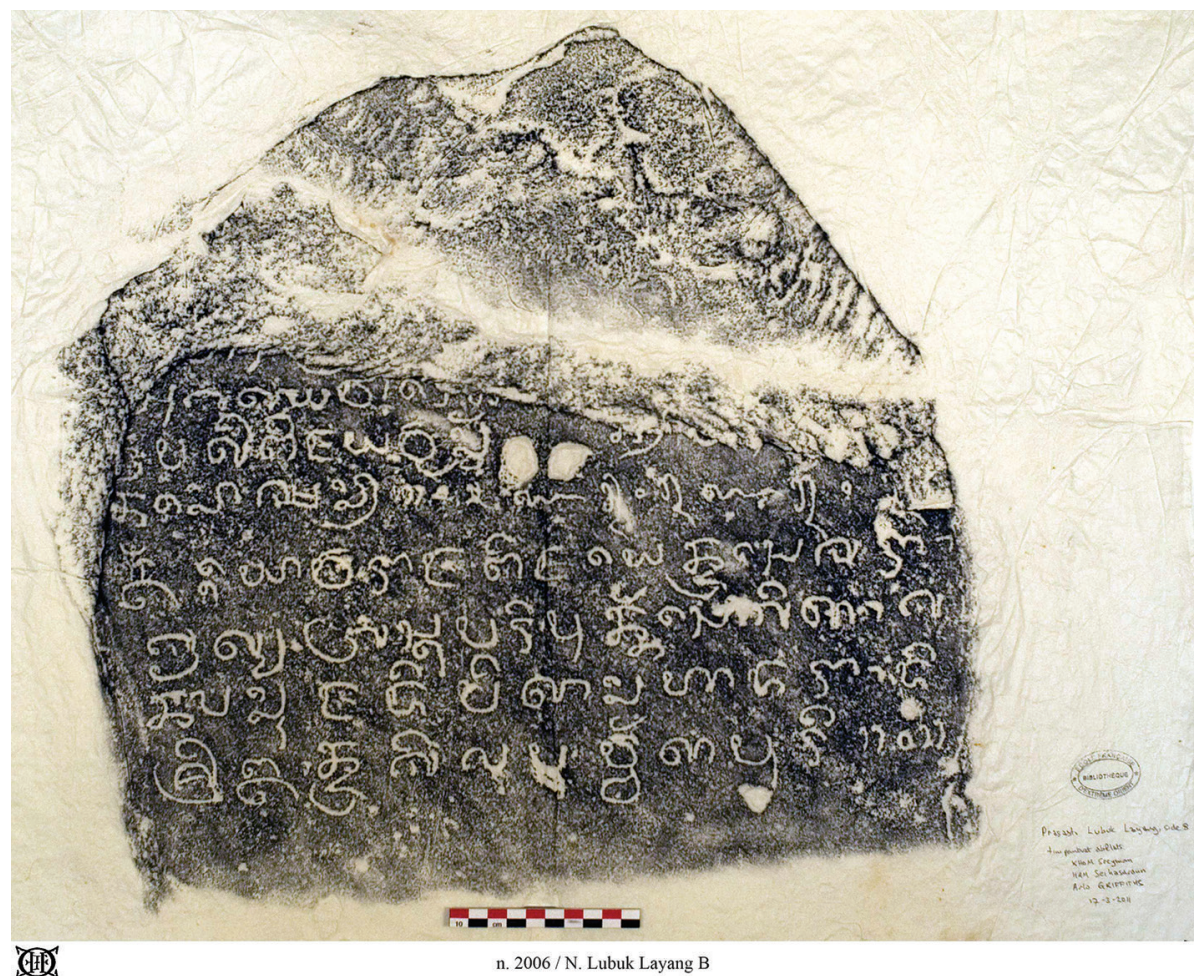

Fig. 4 - Lubuk Layang stela, face B. Estampage EFEO n. 2006. Photo courtesy of the EFEO. 
B (West face, fig. 4)

(1) only traces of two akșaras

$\smile \smile$ (2) sugatayavā(so) $-v-\ldots \cup-\simeq$

(3) (nr)patibijayavarmma - - (n·) $-\smile--$ (4) na mokșam.21

|| 0 || $\boldsymbol{\oplus} / / 0 / / \boldsymbol{q} / / 0 / /$

\section{(5) $\mathrm{Om}$}

yauvarājabijayendrasekharā,

(6) krtya Astu ${ }^{22}$ paripurnna sobhitā,

ka(7)n pamūja di pitā mahādarā,

di (8) śri Indrakila(pa)rvvatāpuri $\|0\|^{23}$

\section{Translation}

Face A:

Indra $\ldots, \ldots$ earth.

$\mathrm{Om}$. Jayendravarman is victorious over the immortals, youthful, subtle; is always mighty (due to?) being one who has the customary practice of the five gifts of worship ( $p \bar{u} j \bar{a})$; he speaks the truth (? sadavacana); is specially devoted to his parents; is a friend for the contentment, health and satisfaction of all people.

Face B:

... abode of the Buddha ... king Vijayavarman, ... death.

$\mathrm{Om}$. May the deeds of the crest-jewel of victorious heirs apparent be perfect [and] beautiful with (kan) zealous (mahādara) offerings (pamüja) to parent(s) in the town of Śrī Indrakīlaparvata.

21. This is the remainder of another Mālinī stanza. See n. 20 . Since we lack $2 \times 15+2$ syllables before sugatayavā(so), we may infer that at least one more line has been lost above the one here numbered 1.

22. krtya Astu: the apparent dot between the two words is probably accidental damage to the stone.

23. The meter is Rathoddhatā, containing four $p \bar{a} d a$, each of which has the pattern 


\section{Commentary}

Although it does not contain a date, this inscription can confidently be dated to the $14^{\text {th }}$ century, based on the similarity of its script to that found in the preceding inscription, in the inscriptions of Ādityavarman, and in the Tanjung Tanah manuscript (Kozok 2015).

Previous scholars have mainly commented on the names figuring in this inscription and proposed various scenarios in which the person or persons whom it celebrates may have been related - politically, chronologically, and in terms of family relationship - with Ädityavarman. I do not have anything to add on those issues, except to warn that any hypothesis is bound to be fragile as long as a comprehensive study of the Ādityavarman corpus has not been undertaken, and as long as the linguistic features of that corpus, to which this inscription seems comparable, are not given due account. In this case, I especially caution against the assumption, which underlies previous discussions of this inscription, that the diversity of names encountered in this text means that we are dealing with more than one protagonist.

Although it is found in a damaged context, the presence of the word sugata indicates that the religious context is (still) Buddhist. The theme of respect for parents and grandparents that we find expressed in two stanzas of the present inscription is also a red thread in the Ādityavarman corpus. ${ }^{24}$

Previous scholars do not seem to have stated explicitly that this inscription is formulated in a kind of mixed language, containing a conjugated Sanskrit verb form (astu) side by side with Malay prepositions (di, kan) and derived forms (pamīja). Such a mixture is not found in the Addityavarman corpus, where a clearer distinction can be made between texts that are wholly or partly in Old Malay (Bukit Gombak I, Gudam II) and all other texts which are in a language that is admittedly very eccentric as Sanskrit, but nevertheless clearly not intended to be Malay. Furthermore, as stated above, the fact that this text is formulated largely, or perhaps entirely, in verse form has also escaped scholarly attention. Since versification is the hallmark of literary aspirations in the Indic cultural world (what Sheldon Pollock has called the "Sanskrit Cosmopolis"), ${ }^{25}$ the fact that the text is at least in some sense linguistically Old Malay combined with the fact that it is composed in verse means that this text constitutes a precious new piece in the puzzle that is the history of Malay literature. ${ }^{26}$

24. Cf. the inscriptions Saruaso II and Paninggahan and the inscription on the Mañjuśri statue from Candi Jago.

25. See Pollock 1996.

26. On this topic, see Griffiths 2018: 279 and Griffiths 2020. 


\section{References}

Balogh, Dániel, and Arlo Griffiths. 2020. "DHARMA Transliteration Guide.” https://halshs. archives-ouvertes.fr/halshs-02272407.

Budi Istiawan. 1992. "Laporan hasil penelitian Prasasti Kubu Sutan, desa Lubuk Layang, kecamatan Rao, kabupaten Pasaman." [Batusangkar]: Suaka Peninggalan Sejarah dan Purbakala Wilayah Propinsi Sumatra Barat dan Riau.

- 1994. "Prasasti Lubuk Layang: tinjauan paleografis dan epigrafis." Amoghapasa 1 (1): 12-18.

Casparis, J.G. de 1980. "Ahmat Majanu's Tombstone at Pengkalan Kempas and Its Kawi Inscription." Journal of the Malaysian Branch of the Royal Asiatic Society 53 (237): 1-22.

Damais, Louis-Charles. 1952. "Études d'épigraphie indonésienne, III : liste des principales inscriptions datées de l'Indonésie." Bulletin de l'École française d'Extrême-Orient 46: $1-105$.

— 1955. "Études d'épigraphie indonésienne, IV : discussion de la date des inscriptions." Bulletin de l'École française d'Extrême-Orient 47: 7-290.

Griffiths, Arlo. 2011. "Inscriptions of Sumatra: Further Data on the Epigraphy of the Musi and Batang Hari River Basins." Archipel 81: 129-75.

- 2012. "Inscriptions of Sumatra, II: Short Epigraphs in Old Javanese." Wacana: Jurnal Ilmu Pengetahuan Budaya 14 (2): 197-214.

- 2014. "Inscriptions of Sumatra, III: The Padang Lawas Corpus Studied along with Inscriptions from Sorik Merapi (North Sumatra) and from Muara Takus (Riau)." In History of Padang Lawas, North Sumatra, II: Societies of Padang Lawas (Mid-Ninth - Thirteenth Century CE), edited by Daniel Perret, 211-53. Paris: Association Archipel.

- 2018. "The Corpus of Inscriptions in the Old Malay Language." In Writing for Eternity: A Survey of Epigraphy in Southeast Asia, edited by Daniel Perret, 275-83. Paris: École française d'Extrême-Orient.

- 2020. "The Old Malay Mañjuśrīgrha Inscription from Candi Sewu (Java, Indonesia).” In Archaeologies of the Written: Indian, Tibetan, and Buddhist Studies in Honour of Cristina Scherrer-Schaub, edited by Vincent Tournier, Vincent Eltschinger, and Marta Sernesi, 225-268. Naples: Università degli Studi di Napoli "L'Orientale."

Guillot, Claude. 2003. Histoire de Barus, Sumatra, II: Le site de Lobu Tua, Étude archéologique et Documents. Paris: Association Archipel.

Guillot, Claude, and Ludvik Kalus. 2008. Les monuments funéraires et l'histoire du Sultanat de Pasai à Sumatra (XIII ${ }^{e}-X V I^{e}$ siècles). Paris: Association Archipel.

Hunter, Thomas M. 2015. "Sanskrit in a Distant Land: The Sanskritized Sections." In A 14th Century Malay Code of Laws: The Nīisārasamuccaya, by Uli Kozok et al., 281-379. Singapore: Institute of Southeast Asian Studies.

Kozok, Uli et al. 2015. A 14th Century Malay Code of Laws: The Nītisārasamuccaya. Singapore: Institute of Southeast Asian Studies.

Machi Suhadi. 1990. "Silsilah Adityawarman.” Kalpataru: Majalah arkeologi 9 (Saraswati: Esai-esai Arkeologi 1): 218-39.

- 1995-96. Prasasti-prasasti Adityawarman. Jakarta: Proyek Pengembangan Media Kebudayaan, Direktorat Jenderal Kebudayaan.

Molen, Willem van der. 2008. "The Syair of Minye Tujuh." Bijdragen tot de Taal-, Land-en Volkenkunde 163 (2-3): 356-75. 
Perret, Daniel, Heddy Surachman, and Ludvik Kalus. 2009. "Six siècles d'art funéraire musulman à Barus." In Histoire de Barus, Sumatra, III: Regards sur une place marchande de l'océan Indien (XII ${ }^{e}$-milieu du XVII ${ }^{e}$ s.), edited by Daniel Perret and Heddy Surachman, 472-506. Paris: Association Archipel, École française d'Extrême-Orient.

Pingree, David. 1982. "A Note on the Calendars Used in Early Indian Inscriptions." Journal of the American Oriental Society 102 (2): 355-59.

Pollock, Sheldon I. 1996. "The Sanskrit Cosmopolis, 300-1300 CE: Transculturation, Vernacularization, and the Question of Ideology." In Ideology and Status of Sanskrit: Contributions to the History of the Sanskrit Language, edited by Jan E.M. Houben, 197248. Leiden: Brill.

Robson, Stuart. 1995. Deśawarnana (Nāgarakrtāgama). Leiden: KITLV Press.

Salomon, Richard. 1998. Indian Epigraphy: A Guide to the Study of Inscriptions in Sanskrit, Prakrit, and the Other Indo-Aryan Languages. New York: Oxford University Press.

Satyawati Suleiman. 1977. The Archaeology and History of West Sumatra. Bulletin of the Research Centre of Archaeology of Indonesia 12. Jakarta: Pusat Penelitian Purbakala dan Peninggalan Nasional, Departemen P \& K.

Zoetmulder, P. J. 1974. Kalangwan: A Survey of Old Javanese Literature. The Hague: Nijhoff. 